\title{
The Making of the (II)Legitimate Citizen: The case of the Pakistan Studies Textbook
}

\section{Ann Emerson}

This paper is intended to contribute to the widening literature on the complicated links between education, the state and violence. It also builds on previous analyses of Pakistan studies textbooks, and utilises notions of citizenship to illuminate inequalities and the theoretical lens of cultural violence. To do this, I present an in-depth analysis of the Pakistan Studies Textbook for Secondary Classes used in government schools in Islamabad Capital Territory. This textbook analysis was conducted as part of a case study of one girls' secondary school in 2014 which linked citizenship education to Galtung's 1990 violence triangle. I also demonstrate through classroom observations of the case study school the power that the textbook holds as the voice of authority in the classrooms in which it is used. The analysis is situated it in the broader historical context of the process of nation building. I illustrate the specific ways the textbook contributes to the narrative of exclusion of some Pakistanis from equal citizenship which has the potential to normalise violence against excluded groups.

Key words: Pakistan Studies; cultural violence; girls' education; social studies education; citizenship education

\section{Introduction}

The purpose of this study is to contribute to the widening literature that explores the multifaceted entanglement between education and violence by combining a critical discourse analysis of the Islamabad Pakistan Studies for Secondary Schools textbook with classroom observations. Bush \& Santerelli identify the two faces of education: one in which education mitigates violence within a state through equal access and positive portrayals and treatment of all citizens (and students) of the state, and the other in which education contributes to identity-based violence through unequal provision and biased curriculum ${ }^{1}$. The current research builds on Bush \& Santerelli's work as well as previous critiques of Pakistani textbooks through a discourse analysis of the Pakistan Study textbook as a key, yet understudied instrument to reproduce cultural violence. This study uses cultural violence to unpack the textbook's narratives of exclusion of some Pakistanis from equal citizenship and the ways it can lead to the legitimisation of violence. The power of the textbook as a sole resource for teaching

\footnotetext{
${ }^{1}$ Bush, K.D., \& Saltarelli,D. eds. 2000. The Two Faces of Education in Ethnic Conflict: Towards a Peacebuilding Education for Children. Florence: United Nations Children's Fund Innocenti Project.
} 
is then demonstrated through evidence from classroom observations conducted during a case study in 2014.

\section{Citizenship Education as Cultural Violence}

Johan Galtung identifies a violence triangle which includes structural, direct and cultural violence. These types of violence support and reproduce one another. Galtung defines structural violence as a process of social injustices evolving into the structures of society. Direct violence is an event or an act in which physical violence occurs. ${ }^{2}$ Cultural violence is defined as any part of culture, exemplified by religion and ideology, language and art, or empirical and formal science to make structural and direct violence look and feel right and rendered acceptable in society. ${ }^{3}$ Cultural violence legitimatizes direct and/or structural violence.

Cultural violence can be linked to discourses of national identity and unequal citizenship when some groups are discursively excluded from equal citizenship. The study of citizenship has the potential to illuminate the ways in which the state discriminates against some citizens through laws, practices, and exclusions which deny some citizens equal access to social justice. Citizenship intersects with the identity of citizens and can be understood as a (re)producer and a representation of social inequalities within societies ${ }^{4}$. Negative understandings of citizens within a state based in a singular aspect of their identity (gender, religion, ethnicity, etc.) links to structural and direct violence against these groups. Citizenship is also linked to nation building projects which attempt to forge together a national identity in order to maintain social cohesion. This is, in part, achieved through narratives of the 'external other', the enemy of the state. ${ }^{5}$

While notions of citizenship are conveyed through a wide variety of institutions and people, citizenship education is usually seen as a particular responsibility of the school. Citizenship is learned in school through both curriculum and daily practices within the school including teaching methods. ${ }^{6}$ Citizenship education can be defined as teaching students their expected roles in society - often based in their identity and the relationship to the identities of others both internal and external to the state. ${ }^{7}$

\footnotetext{
2 Galtung, Johan. 1969. "Violence, Peace, and Peace Research." Jornal of Peace Research 6 (3): 167-191.

${ }^{3}$ Galtung, Johan. 1990. "Cultural Violence." Journal of Peace Research 27 (3): 291-305.

${ }^{4}$ Yuval-Davis, N. 1997. Gender and Nation. London: Sage Publications Ltd.

${ }^{5}$ Ben-Porath, Sigal R. 2009. Citizenship under Fire: Democratic Education in Times of Conflict. Princeton: Princeton University Press.

${ }^{6}$ Shulz, W., Ainley, J., Fraillon, J., Kerr, D., \& Losito, B. 2010. Initial Findings from the IEA International Civic and Citizenship Education Study. Amsterdam: International Association for the Evaluation of Educational Achievement.

${ }^{7}$ Ann Emerson, 2017. Educating Pakistan's Daughters: The intersection of schooling, unequal citizenship and violence. PhD Thesis.
} 
As a key part of citizenship education, textbooks create a narrative that can celebrate the differences among the citizens, or promote a narrow identity of the legitimate citizen. When textbooks omit entire groups of citizens from the pages of the text including ethnic or religious minorities, this also negatively impacts how they are understood as citizens ${ }^{8}$. Therefore, textbooks have the potential to serve as a form of cultural violence by promoting an authoritative narrative of citizenship that excludes some citizens which can lead to structural and direct violence against them. ${ }^{9}$ Additionally, textbook discourses that separate and degrade the external others reproduce negative national narratives of the 'other' for the purpose of creating a unified national identity that is defined by opposing another. Thus, further embedding the importance of the identity of citizens as part of the narrative of 'us' versus 'them'. ${ }^{10}$

According to Saigol, "History and civics...tend to be the most ideologically laden subjects implicated in the formation of national identity ${ }^{11}$." History curriculum creates a national identity by giving the impression that there has long existed a cohesive group that is different from the 'others.' Civics lessons then provides a future of the citizen by using this identity as a promise of participation in the state. These texts and the ideology they promote can contribute to a national identity that celebrates the differences among the citizens, or one which promotes a narrow identity of the legitimate citizen and the exclusion of those who do not fit within that identity from equal rights as citizens ${ }^{12}$.

In the case of Pakistan, the struggle to define a national identity and thus of who is a legitimate citizen is played out in the pages of the textbooks, especially social studies texts. Pakistan Studies, a compulsory subject for all secondary school students in all government and private schools in Pakistan $^{13}$, provides much of the discourse about citizenship for Pakistani students. Saigol explains the importance of Pakistan Studies. She states, "Pakistan Studies tells the official story of Pakistan, how it was created, who opposed it, who fought for it, why it was important to create it, and where it is headed. ${ }^{14}$ It is through these pages that students are exposed to the narratives that shape how citizens are understood in Pakistan. Saigol continued by stating that the official story of Pakistan presented in Pakistan Studies... "tell(s) us who we are, who we are not, how we should think, act and

\footnotetext{
8 Jamal, A. 2006. "Gender, Citizenship, and the Nation-State in Pakistan: Willful Daughters or Free Citizens." Signs 31 (2): 283-304.

9 Davies, L. 2004. Education and Conflict: Complexity and Chaos. London: Routledge.

${ }^{10}$ Saigol, R. 2005. "Enemies Within and Enemies Without: The besieged self in Pakistani textbooks." Futures 37: 1005-1035.

${ }^{11}$ Saigol, R. 2005. Enemies Within and Enemies Without; 1007.

${ }^{12}$ Davies, Lynn. 2004. Education and Conflict: Complexity and Chaos. London: Routledge.

${ }^{13}$ Durrani, N., \& Halai, A. 2018. Dynamics of gender justice, conflict and social cohesion: Analysing educational reforms in Pakistan. International Journal of Educational Development, 61, 27-39.

${ }^{14}$ Saigol, R. 2005. Enemies Within and Enemies Without; 1009.
} 
behave, what we should feel and aspire to and what we must, for the sake of our very survival, forget." 15

\section{Methods}

This textbook analysis was a part of a larger case study of a girls' secondary school in Islamabad, Pakistan in 2014, intended to illuminate the relationship between gendered citizenship education and cultural and structural violence which are reproduced through all aspects of schooling including the Pakistan Studies curriculum and the day-to-day practices of the school. ${ }^{16}$ The Pakistan Studies textbook analysed here served as a foundation for citizenship education within the school (and for all government schools in Islamabad capital territory at the time of data collection).

This Pakistan Studies textbook, written in 2002, served as an all-in-one social studies course for grade 9 and 10 students in the school. The textbook is brief, just 200 pages, and is formatted in mostly bullet pointed statements throughout each chapter. There are exercises at the end of each chapter that include true/false, fill in the blank, and multiple-choice questions. The contents of the text include several chapters on the ideology of Pakistan, a brief history of the making of Pakistan, the resources in the provinces, population and culture, and education.

To unpack the ways in which inequalities are normalized in the textbook, a critical discourse analysis was undertaken. The objective was to analyse the way language is involved in social relations of power and domination and ideology, which can be understood as cultural violence ${ }^{17}$. Critical discourse analysis directly addresses a social problem and focuses on the dominance of elite groups and institutions as they are being enacted, legitimated or reproduced through text and talk ${ }^{18}$. Critical discourse analysis analyses language as constituting society and culture while being situated and historical so that the relationship between discourse and social practices is revealed ${ }^{19}$.

This analysis, therefore, identifies and problematizes the discourses of the citizen throughout the textbook; who is included, who is excluded; who is a legitimate citizen. This analysis was conducted through the use of a historical and intersectional lens to situate the text within the context of broader society. The historical and constitutional content was analysed through comparison to primary historical documents and the broader literature for inaccuracies and omissions. The text was then

\footnotetext{
15 Ibid., 1009.

${ }^{16}$ Ann Emerson. 2017. Educating Pakistan's Daughters: The intersection of schooling, unequal citizenship and violence. PhD Thesis.

${ }^{17}$ Fairclough, N. 2003. Analysing Discourse: Textual Analysis for Social Research. New York: Routledge.

${ }^{18}$ Rogers, R., Malancharuvil-Berkes, E., Mosley, M., Diane Hui, D., \& O'Garro, J. 2005. "Critical Discourse Analysis in Education: A review of the literature." Review of Educational Research 75 (3): 365-416.

${ }^{19}$ van Dijk, Teun A. 2008. "Critical Discourse Analysis." In The handbook of Discourse Analysis, edited by Schiffrin,D., Tannen, D \& Hamilton, H., 352-371. Oxford: Blackwell Publishers Inc.
} 
analysed for the inclusion and portrayal of various groups of Pakistanis by religion, gender, and ethnicity. The frequency of words their placement within the text were analysed to illuminate the relative importance of various concepts and identities. The format of the textbooks was analysed to evaluate the degree to which it contributed to or mitigated critical engagement of students studying the text. Finally, to situate the use of the textbook within the classroom, classroom observations were undertaken with five Pakistan Studies teachers in the case study school. These observations focused on the extent to which the content of the textbook was followed and the opportunities for student engagement in discussions or activities (group work, role play, etc.) that are more likely to promote critical understanding of civic concepts than is lecturing alone. ${ }^{20}$

\section{Contextualizing Pakistan Studies}

The narratives of the Pakistan Studies textbooks are rooted in Pakistan's history of struggle for a unified national identity. Although Pakistan is a Muslim majority state, it is also the home to 6 major ethnic groups and 58 minor linguistic groups. At the time of partition, Pakistan was spread across a wide expanse and separated by the entire country of India dividing East and West Pakistan (now Bangladesh). Ensuring national unity was difficult in the face of this diversity, even with Islam as its cornerstone ${ }^{21}$. In the years following the formation of Pakistan, the struggle to maintain unity among the people was marred by unequal power and resources.

By 1977 after the succession of East Pakistan, internal and external pressures allowed for General Ziaul-Haq to take-over the government and rule as military dictator and president until his death in 1988. To unite Pakistanis and to achieve his personal goals of enjoining Pakistan and Islam under the protection of the military, Zia began an overarching quest for Islamization of the society ${ }^{22}$. His introduction of political Islam, rooted in his own interpretations of the Quran and Sunnah, is often thought to be a turning point in Pakistan from a secular and relatively open society, to one that is highly controlled and staunchly rooted in political Islam ${ }^{23}$ in an attempt to create a national identity.

Zia embarked on a project to create a new ideal of legitimate citizens in his vision of Islam with education reform at the centre. In 1978, as he began his education reforms, Zia stated,

\footnotetext{
${ }^{20}$ Levine, Daniel H., and Bishai, L.S. 2010. Civic Education and Peacebuilding: Examples from Iraq and Sudan. Washington, DC: United States Institutes for Peace.

${ }^{21}$ Lieven, Anatol. 2011. Pakistan: A Hard Country. London: Penguin Group.

${ }^{22}$ Nayyar, A.A., \& Salim, A. 2005. The Subtle Subversion: The state of curricula and texts in Pakistan. Lahore: UNESCO.

23 Jalal, A. 1991. "The Convenience of Subservience: Women and the State of Pakistan." In Women, Islam and the State, edited by Deniz Kandiyoti. New York: Macmillan Press.
} 
The highest priority would be given to the revision of the curricula with a view to reorganizing the entire content around Islam and giving education an ideological orientation so that Islamic ideology permeates the thinking of the younger generation and helps them with the necessary conviction and ability to refashion society according to Islamic tenets ${ }^{24}$.

This Islamization of education was achieved through changes to the curricula of all primary and secondary schools including the addition of Islamic Studies as a compulsory subject and a revision to the social studies curriculum including Pakistan Studies ${ }^{25}$. In the three decades between the end of the Zia administration and the time of this study, there were very few changes to the curriculum in most provinces. This is despite the long-standing criticisms of Pakistani and international educationalists regarding the inclusion of skewed narratives of history, promoting narrow world views, and the exclusion of non-Muslims and women from history and civics lessons ${ }^{26}$.

Pakistan revised its National Curriculum with the support of the U.S. Agency for International Development to replace the content driven curriculum with a competency-based curriculum. However, the funding support of the U.S. in the context of the 'War on Terror' politicised the curriculum revision 'and alienated a range of stakeholders including curriculum and textbook personnel and teachers. ${ }^{27} \mathrm{~A}$ stringent review process ensures that all textbooks comply with the national curriculum. After the devolution of curriculum in 2010, provinces were responsible for curriculum development, yet all provinces endorsed the 2006 curriculum with a few adjustments. The result is that Pakistan Studies textbooks that were developed after 2006 have only included minor changes but have not addressed much of the content developed under Zia-ul-Haq. ${ }^{28}$ The International Rescue Group (2014) stated, "Even after the restoration of democracy in 2008, much of the Zia regime's Islamisation of the curriculum has remained intact." ${ }^{29}$

The author of the Pakistan Studies textbook written in 2002 used for this analysis also acknowledges that there is very little difference in the content of the text from earlier versions. He notes in the preface that, this textbook has changed only in style and presentation, and the content remains largely the same as earlier versions. The result is that the ideology based in Islam that was honed during Zia's

\footnotetext{
${ }^{24}$ Hussian, A., Salim, A., \& Naveed, A. 2011. Connecting the Dots: Education and Religious Discrimination in Pakistan: A Study of Public Schools and Madrassas. Washington: United States Commission on International Religious Freedom. 13.

${ }^{25}$ Dean, B. 2005. Citizenship Education in Pakistani Schools: Problems and possibilities. Lahore: Aga Khan University.

${ }^{26}$ See Kumar 2001, Nayyar \& Salim 2005, Naseem 2010, Rahman 2004.

${ }^{27}$ Durrani, N., Halai, A., Kadiwal, L., Rajput, S., Novelli, M., \& Sayed, Y. 2017. Education and Social Cohesion in Pakistan. UNICEF.

${ }^{28} \mathrm{lbid}$

29 International Crisis Group. 2014. Education Reform in Pakistan. Brussels: International Crisis Group. 14.
} 
rule is evident throughout the pages of this text. The following sections unpack the layers of discourse used by the textbook to promote a singular idea of a legitimate citizen through the use of religious language, narration of struggle for a Muslim homeland, and the othering of Pakistanis throughout the text based on their gender or religion, and the format of the text which discourages critical engagement with the information provided.

\section{The Convergence of Islam and National Identity in the Pakistan Studies Text}

It is on page one, in the chapter titled "Ideological Basis of Pakistan" that the textbook begins the development of the narrative that explains the creation and need for the Islamic State of Pakistan. To this end, the textbook heavily focuses on the ideology of Pakistan as the main source of national cohesion. The ideology, which is based in Islam is intended to create a nationalism that would unite the majority of (Muslim) Pakistanis which come from various ethnic, linguistic, class, and cultural backgrounds ${ }^{30}$. The textbook defines ideology as a

...set of ideas, especially one which a political, cultural, social or economic system is based. Ideology represents the collective consciousness of a group of people in a particular phase of history ${ }^{31}$.

However, the presentation of the ideology in the textbook promotes a concept that goes beyond shared ideals to creating a rationale for the existence of Pakistan as a divine right of the Muslims of South Asia. According to the section, "Pakistan Ideology in the Islamic Perspective", there are six main points included in the ideology. These are,

1. The Two Nation Theory: Muslims believe that the people of the world are divided into two groups. The followers of Islam are a separate and distinct nation from the rest of mankind.

2. Sovereignty of Allah: Allah's authority encompasses a Muslim's entire life and it permeates in all its spheres.

3. Justice: It is the duty of the Islamic state to administer justice in all spheres of human life, may it be moral, social, political or economic.

4. Equality and Fraternity: No human being is superior to another on the basis of colour and race, the only thing which distinguishes a person from other is God-fearing and purity of soul.

5. Equal rights for Non-Muslim Citizens: Non-Muslim citizens of an Islamic state have equal social status with the Muslim citizens.

\footnotetext{
${ }^{30}$ Rahman, T. 2004. Denizens of Alien Worlds: A study of education, inequality and polarization in Pakistan. New York: Oxford University Press.

${ }^{31}$ Khan, A.Q. 2010. Pakistan Studies for Secondary Classes. 1.
} 
6. Democracy: Allah has enjoined upon the head of a Muslim state to consult with the common body of citizens ${ }^{32}$.

The presentation of the 6 points in the first few pages of the textbook uses words relating to Islam in each of these six points and reiterates the Islamic basis of Pakistan as well as the importance of the Islamic identity for its citizens.

The textbook uses ideology to promote the bond between Islam and Pakistan as the reason for the formation of the country. It states that communities and nations are established with a purpose and objective. And therefore, The State of Pakistan was... "...established with an objective to devise a system based upon total subservience to Allah's commands" ${ }^{\prime 33}$. This is in contrast to the literature about partition, which posits that the leaders of the time did not have a clear idea of what the ideology should be or how it should be translated into practice in terms of the economic, political and social structures of the new nation. Weiss (2014) concludes:

...with various forces pulling in different directions, an overriding concern for the long-term security of the new political entity, little attention was initially paid to the state having a distinct ideology or to the kinds of social policies it would pursue. There was far greater concern for its very existence ${ }^{34}$.

However, because the Pakistan Studies curriculum was developed as part of General Zia's Islamization project, the textbook presents a narrative that the link between Pakistan and Islam was always strong. Furthermore, the textbook makes clear the importance of Islam over any other identity or national characteristic. This is evidenced by the frequency of the use of words relating to Islam (e.g. Islam, Muslim/s, Allah, and Prophet). These words are written 54 times before the word Pakistan appears in the text in this quote, The State of Pakistan was... established with an objective to devise a system based upon total subservience to Allah's commands ${ }^{35}$. This asserts the importance of the Muslim identity over the Pakistani identity while making the two inseparable.

Additionally, the language used in the text can be understood in terms of cultural violence by asserting that being a good Muslim and human nature are nearly the same and their behavior is divinely ordained as is illustrated in the following quotes:

\footnotetext{
32 Ibid., 3-4.

33 Ibid., 4.

${ }^{34}$ Weiss, A.M. 2015. Interpreting Islam, Modernity, and Women's Rights in Pakistan. New York: Palgrave Macmillan.15.

${ }^{35}$ Khan, Pakistan Studies for Secondary Classes; 4.
} 
A Muslim individual and a Muslim community are bound to follow the path of Allah. This is a simple path to traverse, because it is very close to human nature ${ }^{36}$.

The norms which guide the behaviour of a Muslim in his or her private life, in relation to the universal Muslim community, and the principles that determines how a Muslim should interact with other human beings is divinely ordained ${ }^{37}$.

By making these assertions, the textbook contributes to the narrative of Islam as the most important identity in Pakistan. In doing so, produces a form of cultural violence by making this one aspect of a citizen's identity seem natural and in fact, ordained by God, creating a valid separation from other human beings. This, then, contributes to the construction of legitimate citizens of Pakistan as followers of Islam and ultimately to the acceptance of structural violence and in some cases direct violence against those citizens who do not fit within this identity.

\section{Constructing History, Nation Building and the 'Other'}

This discourse which links Pakistan and Islam is also evident in the historical narratives told throughout the lessons. The textbook uses the technique of 'othering' to create a sense of Pakistani citizenship based in an identity that is meant to unify the peoples of Pakistan by positioning them in a binary opposition to the other; a technique common in nation building discourse and in wartime citizenship to ensure that citizens remain or become united as a single nation. ${ }^{38}$

To this end, the Pakistan Studies text focuses on the development of the Islamic Republic of Pakistan. It begins with pre-partition and goes through the secession of East Pakistan (now Bangladesh). Each of these stories focuses on the "Pakistan Movement" which was the movement within colonial India for a separate homeland for Muslim Indians. The text does not focus on the shared history of the anticolonial movement. The story of partition and independence from Britain told in the textbook presents a story of a unanimous movement for a Muslim state to escape the hegemonic rule of the Hindus and that the intended purpose of the new nation was to be based in an Islamic ideology. It begins the narrative of the hegemonic behaviour of the Hindus in the 1857 War of Independence against the British rulers. It states that the war was lost due to disorganization and notes:

Although the Muslims and the Hindus both had joined hands in fighting against the British, the Muslims were held solely responsible for the upheaval and made to suffer great hardship.

\footnotetext{
36 Ibid., 1.

37 Ibid., 2.

${ }^{38}$ Ben-Porath, S. 2009. Citizenship under Fire: Democratic Education in Times of Conflict. Princeton: Princeton University Press.
} 
It goes on to illustrate how the Muslims were strong and proud, but the Hindus were opportunists. The text states:

Their [Muslims] loss of life and property had been great, but in spite of all this, their pride would not let them bow down to the British. Hindus, however, did not take much time to shift their position and it was soon felt that they would go to any extent to please their new masters. ${ }^{39}$

However, the Pakistan Movement was not unanimous. Indian Muslims of the time had various perspectives about their futures. Some of the most religious groups did not support the creation of Pakistan as they believed that Islam could not be constrained within the borders of a nation-state. Other Muslim groups did not agree that independence from Britain was a necessity. ${ }^{40}$

The separation of Muslims from other people of the world, and especially Hindus is prominent throughout the text. For example, before the textbook even mentions the word Pakistan, it separates Muslims from Indians. On page 3 the textbook describes the two-nation theory and states that:

From the Muslims' point of view all non-believers of the world are a single millat (or nation). Indian Muslims were no exception to this rule, they did not form a part of the wider Indian nationhood, as some people had mistaken. ${ }^{41}$

To continue to reinforce the national identity formed in alienation from the Hindu other, the textbook repeatedly uses negative language to describe Hindu leaders and blames them for events that are not seen as favourable to Muslims without addressing any historical complexities. In the section titled "The Quaid-Azam (RA) and the Pakistan Ideology", Jinnah is lauded as the "greatest proponent of Hindu/ Muslim unity to rid India of British imperialism." The book states that Jinnah achieved success at uniting Hindus and Muslims against the British and he achieved the title "the Ambassador of Hindu Muslim Unity." The text goes on to explain that his successes was short-lived and the Congress was soon overpowered by "extremist Hindu leadership." It goes on to laud Jinnah's conviction to creating a united India, but it states that his plan could not materialize, "mainly due to the arrogance of the Congress hot-heads like Jawaharlal Nehru and Patel." ${ }^{42}$

\footnotetext{
${ }^{39}$ Khan, Pakistan Studies for Secondary Classes; 18.

${ }^{40}$ Weiss, A.M. 2015. Interpreting Islam, Modernity, and Women's Rights in Pakistan.

${ }^{41}$ Khan, Pakistan Studies for Secondary Classes; 3.

42 Ibid., 8.
} 
The negative language used to describe Hindus escalates as the text covers the creation of Pakistan and the troubles it soon faced in maintaining a united country, including both East and West Pakistan. In a section about the role of Jinnah after the founding of Pakistan, the textbook states:

The enemies started making hostile propaganda against Pakistan from the very first day of her birth. They were spreading rumours that Pakistan was not economically viable and that she would soon collapse like a house of $\operatorname{cards}^{43}$.

In the Chapter, "The Islamic Republic of Pakistan", there are two sections on the succession of East Pakistan (Bangladesh) titled, "The Fall of East Pakistan" and "The Two Nation Theory and the East Pakistan Tragedy". These sections outline the events that led to the succession of Bangladesh from Pakistan. The first section gives a seven-point list of reasons for Bengali discontent and while it does acknowledge some of the valid reasons for the Bengali discontent with West Pakistan, it also places heavy blame on the Hindu leadership of India as well as the Hindus living in East Pakistan.

It states:

The Indian leadership in general did not agree with the idea of creating a separate homeland for the Muslims. When Pakistan was created to their entire displeasure, they started working on the agenda of dismembering it without delay. East Pakistan's soil proved very fertile for them for several reasons. Firstly, that the province had a very big Hindu population, which, unlike West Pakistan Hindus, had deep pro-India sympathies. Secondly, that these Hindus were economically well off and well-educated. In many schools, colleges, and universities Hindu teachers outnumbered Muslim teachers. These institutions with the passage of time virtually turned into nurseries for breeding anti-Pakistan and secessionist intelligentsia. These intellectuals played a decisive role in dismembering Pakistan. East Pakistani masses, which felt deprived and oppressed by the West Pakistan fell an easy prey to the secessionist. ${ }^{44}$

This continues the narrative that Pakistan was a victim of Hindu schemes that led to the secession of Bangladesh. In doing so, it does not portray the difficulties faced by the Bengalis due to the power of West Pakistan and the atrocities that West Pakistan imposed on Bengalis during the nine-month war ${ }^{45}$. Additionally, the textbook does not take into consideration the complexities of the war for those in East Pakistan including internal struggles in East Pakistan between the Bengalis and non-Bengalis as

\footnotetext{
43 Ibid., 38.

44 Ibid., 57.

45 Sharlach, L. 2000. "Rape as Genocide: Bangladesh, the Former Yugoslavia, and Rwanda." New Political Science 22 (1): 89-102.
} 
well as those who supported succession and those who did not ${ }^{46}$. Even when the textbook admits that conditions were not good for the Bengalis, it does so in a way which delegitimizes the Bengali claims. As is shown in the example below:

A long period of military dictatorship marked with undemocratic practices was the major cause of unrest. Bengalis said they were being neglected and being subjected to political repression ${ }^{47}$.

By using the phrase, "Bengalis said..." it gives this impression that these claims were false and therefore not legitimate. This is especially noticeable when compared to the certainty in other statements in the chapter mentioned above, like, "These [Hindu] intellectuals played a decisive role in dismembering Pakistan."

In this chapter, the description of the secession of East Pakistan is done in terms that are catastrophic and imply a victimization of Pakistan. Also, the words used to describe the events are selected to sound like a human death and include phrases like "death blow" and the 'dismemberment of Pakistan." And all of this is attributed to the wrong-doings of India. The section on the Two Nation Theory and the East Pakistan Tragedy begins by stating that, "India, no doubt, played an important role in breaking Pakistan into two parts." It then goes on to say that:

Indira Gandhi very arrogantly claimed that the Two Nation Theory had sunk into the Bay of Bengal just as the Bangladesh flag was unfurled. These remarks were unfair and they are naturally so because Mrs. Gandhi was a party to the whole matter and she had exerted all her negative potentials to make things happen the way she liked ${ }^{48}$.

This narrative of Hindu conspirators going to great lengths to ensure the failure of Pakistan is woven through the history lessons of the textbook to reiterate the divide between Pakistan Muslim and Hindu Indian identities. It solidifies the idea of the threatening other, the common enemy against which all Pakistanis must defend their country and their Muslim identity.

The textbook also downplays Pakistan's loss of the nine-month war and uses the story to reinforce the bond of Muslims and the Two Nation Theory. The text emphasizes that Bangladesh did not accept "Indian hegemony as many people in Pakistan predicted it would. It did not forsake her Islamic

\footnotetext{
${ }^{46}$ Bose, S. 2005. "Anatomy of Violence: Analysis of Civil War in East Pakistan in 1971." Economic and Political Weekly 40 (41): 4463-4471.

${ }^{47}$ Khan, Pakistan Studies for Secondary Classes; 57.

48 Ibid., 62.
} 
identity." It does not directly discuss the war in any way, but simply says, "After the cessation of hostilities, broken bonds of brotherhood were restored." 49

At the time, the Pakistan Studies textbooks were originally written, Zia-ul-Haq needed to create a sense of national unity as it was feared that other provinces would attempt to secede from Pakistan for similar reasons that Bangladesh did including unequal resources and power distribution. Therefore, the emphasis on the external threatening other portrayed in the textbooks was included in the texts to create a common enemy whom all Pakistanis should protect the state from. Kumar argues that the result of this was...the internalization of a masculine, war oriented and essentially antiHindu ideal of the nation-state. ${ }^{50}$ This along with the focus on the Islamic Ideology of Pakistan conflate the notions of religion and patriotism. And therefore, a good citizen of Pakistan should be willing to fight for their Muslim identity. While this narrative serves its purpose of creating a national identity, it also reinforces the notion of Muslims as the legitimate Pakistanis while engaging with violent/ war time rhetoric. This combination serves clearly as cultural violence by making structural and even direct violence against these external 'others' acceptable, and in some cases glorified in society.

\section{The Others Within}

\section{A Separate and Distinct Nation}

The focus on the 'other' created through the historical construction of Pakistan does not stop outside of the borders of Pakistan, but by extension includes the 'others' that are living within the country, and in fact are citizens of Pakistan. In the pages of the text, these others are primarily understood as the $3-6 \%$ of the citizens of Pakistan who are not Muslim. Apple argues that textbooks "... embody a vision of legitimate knowledge and culture and in the process of enfranchising one group's cultural capital, disenfranchises another's". ${ }^{51}$ Nayyar argues that the Pakistan Studies textbook for Grades 9 and 10 emphasis of Pakistan being created based in religious ideology does just this. He argues that this has been done with, "...little [realization] that defining a nation on the basis of one religion can cause alienation among Pakistanis of other faiths, thus negating the nation building process." 52

The textbook often portrays non-Muslims as a separate type of citizen than Muslims. References to non-Muslims are made to illustrate how they fit into the Muslim state, and how they do not. The

\footnotetext{
49 Ibid., 64.

${ }^{50}$ Kumar, Prejuduce and Pride; 59.

${ }^{51}$ Apple, M.W.. 1992. "The Text and Cultural Politics." Educational Researcher 21 (7): 4-19. P.5.

52 Nayyar, A.H. 2013. A Missed Opportunity: Continuing Flaws in the New Curriculum and Textbooks after Reforms. Islamabad: The Jinnah Institute.; 5.
} 
textbook emphasizes that Muslims are their own community and are different from the rest of the world including the below passage from page 3 of the text:

Muslims believe that people of the world are divided into two major communities or millats on the basis of faith. Followers of Islamic creed are a separate and distinct nation from the rest of the mankind. ${ }^{53}$

The textbook also emphasises laws that focus on Muslim and non-Muslim rights separately. For example, the salient features of the Objectives Resolution of 1949 which was to be the basis of the first constitution of Pakistan are included in the text. Of the eight features, 5 points specifically mention Allah or Muslims and include that power to rule the state has been delegated by Allah. The fifth point states that "Facilities will be provided to the Muslims in order to enable them to fashion their lives in accordance with the teachers of Quran and Sunnah." ${ }^{54}$ After which, the list states "NonMuslims will be guaranteed all fundamental human rights, particularly the rights of religious and cultural development." ${ }^{55}$ While this acknowledges the rights of non-Muslims, the separate rights, contributes to the rhetoric of difference rather than a unified national identity. Furthermore, the limits of non-Muslim citizenship are also included. It is also noted in both the section on the first constitution of Pakistan of 1956, and in the Islamic Provisions of the 1973 Constitution that, "Only a Muslim believing in the unity of Allah and the finality of the Prophet Muhammad (PBUH) shall qualify for the offices of the President and the Prime Minister." ${ }^{156}$ This exclusion from the highest political offices can indicate to students that non-Muslims are in fact not legitimate citizens of Pakistan.

Nearly the entire text promotes the ideology of Pakistan and the narrative of Jinnah's desire for a Muslim state, it is not until the last chapter "Pakistan: A Welfare State" that the textbook revisits the responsibilities of the citizens of an ideological state as were defied by Mohammad Ali Jinnah in 1947. In point 5 "All discrimination to be defied", it adds that all citizens are created equal and includes this quote from Jinnah's speech Constituent Assembly on 11 August 1947, three days prior to independence,

You are free; you are free to go to your temples; you are free to go to your mosques or to any other places of worship in the state of Pakistan. You may belong to any religion or caste or creed... that has nothing to do with the business of the state. ${ }^{57}$

\footnotetext{
53 lbid., 3.

54 lbid., 50.

55 lbid., 51.

56 lbid., 66.

57 Ibid.,192.
} 
The preceding chapters present a Pakistan that is solely based in Islam and a representation of Jinnah's vision for Pakistan seem to contradict the above quote. In part, this is due to Jinnah's shift in ideas about Pakistan. Prior to the creation of Pakistan, Jinnah focused heavily on the Two Nation Theory and cultural divisions between Muslims and Hindus. However, after the creation of Pakistan, Jinnah changed his rhetoric to support a secular state that welcomed all citizens. ${ }^{58}$

The placement of this quote in the last chapter of the book, after it has been repeatedly established that Pakistan is an Islamic state downplays the importance of this statement. Additionally, this quote excludes the beginning and the second half of Jinnah's statement which makes clear his ideas regarding equality, citizenship, religion and the state. It starts,

To my mind, this problem of religious differences has been the greatest hindrance in the progress of India. Therefore, we must learn a lesson from this. ${ }^{59}$

He continued,

... We are starting with this fundamental principle: that we are all citizens, and equal citizens, of one State. ... Now I think we should keep that in front of us as our ideal, and you will find that in course of time Hindus would cease to be Hindus, and Muslims would cease to be Muslims, not in the religious sense, because that is the personal faith of each individual, but in the political sense as citizens of the State. ${ }^{60}$

This quote when read in full indicates that Jinnah did not envisage a theocratic government, but wanted a separation of religion and state. While it may be that the quote being edited this way may be merely a means to saves space in the textbook, it could also be understood as a deliberate attempt to maintain the narrative created throughout the text of a unanimous movement for a Muslim state. In a 2013 article for the Pakistani English newspaper, The Express Tribune, educationalist A.H. Nayyar asserts that,

...the August 11 speech was not discussed in public for decades. The founder's vision was rediscovered in the 1980s when it was used to resist General Zia-ul-Haq's attempt at turning

\footnotetext{
58 Parel, Anthony J. 2008. Gandhi's Philosophy and the Quest for Harmony. Cambridge: Cambridge University Press.

${ }^{59}$ Khan, A.M. 2003. "Persecution of the Ahmadiyya Community in Pakistan: An Analysis Under International Law and International Relations." Harvard Human Rights Journal 16: 217-244.; 222.

60 Nayyar, A.H. 2013. A Missed Opportunity: Continuing Flaws in the New Curriculum and Textbooks after Reforms. Islamabad: The Jinnah Institute.
} 
Pakistan into a theocracy. Having failed to suppress Jinnah's statements, today the supporters of theocracy in Pakistan are trying to distort them. ${ }^{61}$

The treatment of history and the constitution in the Pakistan Studies text is done to create a narrative of Pakistan that claims it has always been a theocratic state which was unanimously agreed upon throughout its history. To achieve this, the textbook leaves out key pieces of the constitution that do not fit into this narrative, including Article 22(1) of the Constitution which states,

No person attending any educational institution shall be required to receive religious instructions, or take part in any religious ceremony, or attend religious worship, if such instruction, ceremony or worship relates to a religion other than his own. ${ }^{62}$

This Constitution Article prohibits Islamic teaching to those who are not Muslim. Yet, Pakistan Studies (as well as several other subjects) is based in Islam and therefore a direct violation of this Article.

The selected history told in Pakistan Studies is meant to create a national identity based on its majority population. However, the differentiated discursive treatment of non-Muslims and the choices of what is included and excluded reinforce ideas of legitimate citizenship; the text makes clear that Pakistan belongs to Muslims, and these 'others' are living within their borders. By doing so, reproducing the cultural violence that leaves space for the legitimisation of structural violence against non-Muslims of Pakistan.

\section{Where Women (do not) Belong}

In the case study school, a girls' school the Pakistan studies textbook is meant to serve as a glimpse into their future as citizens. However, the textbook offers few mentions of women citizens. Often women in Pakistan, including Muslim women, are positioned alongside other minorities as excluded from the same type of citizenship their male counterparts enjoy. ${ }^{63}$ This is due in part, to the historically constructed role of women in Pakistan as supporters of men, responsible for the matters of the home and excluded from national history. The textbook is a strong example of this as it nearly completely omits women from its history lessons. This is despite the fact that women contributed to the Pakistan Movement prior to independence and after. For example, in addition to the work of Jinnah's sister, Fatima Jinnah, and other well-known aristocratic women, The Muslim League Party created a "committee of ladies" to enable women to participate in the work of the Muslim League to promote the Pakistan Movement. These women organized district and provincial women's sub-committees, enlisted more women in the Muslim league and carried out "intensive propaganda amongst Muslim

\footnotetext{
61 Ibid.

62 Government of Pakistan. 1977. The Constitution of the Islamic Republic of Pakistan.

${ }^{63}$ Naseem, M. A. 2010. Education and Gendered Citizenship in Pakistan. New York: Palgrave Macmillan.
} 
women throughout India in order to create in them a sense of a greater political consciousness." 64 The women's committee also advised Muslim women on enriching Muslim society. In his 1940 speech, Jinnah noted,

This central committee, I am glad to say, started its work seriously and earnestly. It has done a great deal of useful work. I have no doubt that when we come to deal with their report of work done we shall really feel grateful to them for all the services that they have rendered to the Muslim League. ${ }^{65}$

This fact is not mentioned in the textbook. Additionally, despite the prominence of Fatima Jinnah in the Pakistan Movement, she is not mentioned in this text (although she is discussed in other textbooks). In fact, the history sections of the text reference women only once. In the section, "Quaid-e-Azam's Role as the First Governor General of Pakistan" in the list of 'important advice' for the new nation of Pakistan. It states,

The Quaid-e-Azam (RA) exhorted upon the public servants that they should devise a system under which women are able to make a fair contribution in the progress of the country and it is ascertained that they receive their due share of opportunities. ${ }^{66}$

However, this quote is not followed up with any examples of how this was or was not done. Additionally, while none of the women who have contributed to the building of the nation of Pakistan are mentioned by name, there is one woman who is named. Indira Gandhi, the Prime Minister of India during the succession of East Pakistan is discussed regarding her role in the secessionist movement. She is described as a villain (see previous section) and referred to as Mrs. Gandhi, while men in the text are referred to by their surnames or full names (not as Mr.). The use of the prefix Mrs. emphasizes her status as a married woman and detracts from her status as the leader of a state.

In addition to not acknowledging the women involved in the history of Pakistan, the other sections of the textbook equally ignore women as citizens of Pakistan. When women are mentioned in the textbook in the chapter on the population of Pakistan, they are described as a burden to the economy. The text states the following,

\footnotetext{
${ }^{64}$ Jinnah, M. 1940. "Address by Quaid-i-Azam Mohammad Ali Jinnah at Lahore Session of Muslim League." Lahore: Directorate of Films and Publishing; Government of Pakistan.

${ }^{65} \mathrm{lbid}$

${ }^{66}$ Khan, Pakistan Studies for Secondary Classes; 37.
} 
The contribution of female workforce in economic development is only $2.02 \%$. Women... form the larger but dependent portion of Pakistan's population. Percentages of women in the labour force is 13.5 as compared to the men's $86.5 \% .{ }^{67}$

There is no reason given for the difference in participation (including cultural and religious practices) in the labour market nor does it acknowledge the work that women do in the home. It problematizes women by calling them the 'larger but dependent' portion of the population. This wording describes women as a burden (dependent) on society rather than as contributors. This is consistent with Mumtaz \& Shaheed's 1987 book, which illuminated the struggles of women during the Zia era. They state,

Nowhere are the physical hardship endured by women or their contribution to production acknowledged. Rather, such realities are either ignored or actually negated by society's attitudes towards and treatment of women. ${ }^{68}$

The textbook, which had undergone few substantial changes between the first edition written under Zia and the time of the case study illustrates that women are still not being acknowledged for their contribution to society.

By excluding women from the history of Pakistan, the textbook offers the female students of the case study school no guidance on the contributions of women in the development of Pakistan and leaves girl students then with little to guide them as to how to contribute to their nation as citizens. Additionally, the small mention about the way in which women seem to burden the economy, leaves very little room for girls to imagine their own place as citizens of Pakistan, or how they might be empowered to contribute to change within their own country. This lack of representation in textbooks means that female students must depend much more on the day-to-day practices of schooling to model/teach them to be future citizens. ${ }^{69}$

\section{Formatted for Indoctrination}

In addition to the content of textbooks, how they are structured also impacts the ways in which students understand their world. The Pakistan Studies book is brief and often uses a bullet pointed format. This type of format has been criticized as counterproductive to encouraging students to critically engage with the content of the text. The highly compressed stories in the text discourage

\footnotetext{
67 Ibid., 145.

${ }^{68}$ Mumtaz, K. and Shaheed, F. 1987. Women of Pakistan: Two Steps Forward, One Step Back. London: Zed Books Ltd. P.23.

${ }^{69}$ Ann Emerson, 2017. Educating Pakistan's Daughters: The intersection of schooling, unequal citizenship and violence. PhD Thesis, University of Sussex.
} 
students from asking for details or to consider complexities beyond the simple stories told in the book. Kumar argues that the purpose of this format is to indoctrinate, rather than explain. ${ }^{70}$ Saigol claims this is done in Pakistan Studies textbooks to create a specific homogenous identity. She states,

Information in little bits and pieces, without any underlying principle tying the pieces together, works in the construction of identity by enabling a mass, collective amnesia of the unspoken and of the unwritten relations or contradictions between bits of knowledge. ${ }^{71}$

Each chapter ends with student exercises that consist of fill in the blank statements and true or false questions that are mostly filling in names and dates. There are also a few 'opinion' questions for which answers are directly found in the chapter. These exercises are typically done in class by the teacher reading the question and the students calling out the answers in the case study school. Chapter exercises then reflect the information that students must retain for the exams which keeps the focus on facts covered in the questions rather than the details of the contents of the chapter. ${ }^{72}$

For example the questions found at the end of the chapter about the secession of East Pakistan focus on the idea that Islam has won against the Hindu opposition while ignoring Pakistan's loss of the war. Examples include:

- Describe the events leading to the dismemberment of Pakistan. Also explain the Indian role in this regard. When was Bangladesh proclaimed, and;

- The fall of East Pakistan served as a death blow to the Two Nation Theory. Do you agree with the statement? Give reasons to support your argument. ${ }^{73}$

Both questions emphasize the personal nature of the destruction of Pakistan by again using the words dismemberment and death blow. Additionally, the second question appears to be an opinion question, but in fact the answer is found directly in the text in the following passage,

...it is not fair to interpret the separation of East Pakistan as a death blow to the Two Nation Theory. ${ }^{74}$

The types of questions, in which students are not encouraged to engage with content beyond the restating of the text, minimise students' engagement in civic understanding. Therefore, the role of

\footnotetext{
${ }^{70}$ Kumar, K. 2001. Prejudice and Pride: School histories of the freedom struggle in India and Pakistan. New Delhi: Viking by Penguin Books.

${ }^{71}$ Saigol, R. 2005. "Enemies Within and Enemies Without: The besieged self in Pakistani textbooks." Futures 37; 1019.

72 Kumar, Prejudice and Pride.

${ }^{73}$ Khan, Pakistan Studies for Secondary Classes; 71.

74 Ibid., 64.
} 
teachers becomes imperative in interpreting the text and encouraging students to engage with information more critically and in-depth.

\section{The Textbook in the Classroom}

The power of textbooks to serve as an authoritative voice on national narratives relies on the ways in which the textbooks are used in the classroom and the extent to which teachers themselves buy-in to the ideology promoted. In cases where teachers resist the content or re-interpret content, the textbook loses this power ${ }^{75}$. However, in the classrooms observed in the case study school, the textbook held an important place. For many of the teachers, the narratives in the text were similar to those they had grown up with and the Pakistan Studies teachers used the textbooks to guide each class period. Additionally, classrooms were under resourced and the textbook was the only learning resource available in the classroom; there were no teachers' guides or additional student material to enhance student's understandings of the topics covered in the text. This strong emphasis on the text and short class periods ( 35 minutes) left teachers very little time to expand upon the content of the text or to engage students in discussion, leaving the textbooks to serve as the authoritative voice, and limiting the teachers' voices as interpreters of discourse.

In the classrooms observed, there were several missed opportunities for teachers to utilize discussion or activities to critically engage students with the ideas presented in the textbook. All of the teachers observed relied upon lecturing as the primary method of instruction; and most read directly from the text, giving few opportunities for students to engage in the content. For example, one teacher read the textbook aloud stopping only to ask students if they understand words, but not waiting for their answers and herself giving the translation in Urdu. Quotes from Jinnah regarding freedom of religion were part of the lesson. The teacher read through these quickly without stopping to discuss the implications of these statements or the relationship to Pakistani society today. This, therefore, created a missed opportunity for discussion about Pakistanis of all religions as citizens. Another experienced teacher was able to recite the textbook to the class without having to read it, and asked students to respond by raising their hands to the closed-ended questions at the end of the chapter. Only one teacher used alternative teaching methods to the teacher centred approaches of her colleagues. Although she read from the book, she allowed the students to work in pairs to discuss the questions at the end of the chapter. However, this was cut very short because of the short class period.

\footnotetext{
75 vom Hau, M. 2009. Unpacking the School: Textbooks, Teachers, and the Construction of Nationhood in Mexico, Argentina, and Peru. Latin American Research Review, 44, 127-154.
} 
The lack of varied teaching methods impacts the teaching of citizenship in several ways. First, while learning civics can be done through content (of which there is very little in this case), teaching methodology also impacts students' views and understanding of citizenship. Active techniques like discussion and role-play have been shown to be more effective than lecture to engage students in civic concepts. ${ }^{76}$

\section{Conclusion}

The Pakistan Studies textbook contributes to a singular identity of an ideal citizen through a discourse of othering first the Indians and then by extension to the religious minorities and women within Pakistan. It contributes to a strong narrative of 'us against them' which permeates how citizenship is both understood and performed by different citizens in Pakistan. The impact of the textbooks on identity is evidenced in a study of primary school children, in which Durrani \& Dunne found that 33.8 percent of children would identify themselves to someone they did not know as Muslims compared to 24.1 percent of students who would identify themselves as Pakistanis. They also found that ideas of 'other' were represented as negative drawings of Hindus or Indians and some students included images of the Unites States. ${ }^{77}$ This othering through education can have long lasting implications as was demonstrated in Voigtländer \& Voth's findings that Germans who were indoctrinated through schooling during Hitler's era remained more anti-Semitic throughout their lives than those born before or after that period. ${ }^{78}$

The discourse of exclusion and narratives of a singular Pakistani identity portrayed in the textbook serve as cultural violence by laying a foundation for the justification of excluding fellow citizens, especially women and religious minorities from the discourses (and rights) of legitimate citizens. The textbook does little to include women which serves to position women as absent from the public sphere, where citizenship takes place, but in the home protecting the ideological understanding of the Islamic Republic. ${ }^{79}$ Cultural violence is also demonstrated by promoting the notion that those who fall outside of that identity have been created unequal in the eyes of God. In this case, the textbook represents cultural violence against those who do not fit within the construct of a legitimate citizen by positioning them as the 'other'. By serving as a discourse of cultural violence, the textbook has the

\footnotetext{
${ }^{76}$ Levine, D. H., and Bishai, L.S. 2010. Civic Education and Peacebuilding: Examples from Iraq and Sudan. Washington, DC: United States Institutes for Peace.

${ }^{77}$ Durrani, N, \& Dunne, M. 2010. "Curriulum and National Identity: Exploring the links between religion and nation in Pakistan." Journal of Curriculum Studies 42 (2): 215-240.

${ }^{78}$ Voigtländer, N., \& Voth, H.-J. (2016). Nazi Indoctrination and anti-Semetic Beliefs in Germany. PNAS, 112(26), 7931-7936.

79 Durrani, N, \& Dunne, M. 2010. "Curriulum and National Identity: Exploring the links between religion and nation in Pakistan." Journal of Curriculum Studies 42 (2): 215-240.
} 
potential to contribute to the justification of structural violence, and in the worst cases to direct violence against some citizens. 